\title{
Top-down modification of bottom-up processes: selective grazing reduces macroalgal nitrogen uptake
}

\author{
Matthew E. S. Bracken ${ }^{1, *}$, John J. Stachowicz ${ }^{2}$ \\ ${ }^{1}$ Bodega Marine Laboratory, University of California at Davis, PO Box 247, Bodega Bay, California 94923, USA \\ ${ }^{2}$ Section of Evolution and Ecology, University of California, One Shields Avenue, Davis, California 95616, USA
}

\begin{abstract}
Although nutrient availability and oceanographic context can influence top-down processes in intertidal communities, the reciprocal effects of consumers on bottom-up processes, such as nitrogen uptake by macroalgae, are less well-documented. We used a combination of field observations, mesocosm experiments, and laboratory nitrate-uptake measurements to evaluate the interaction between the kelp crab Pugettia producta and its preferred food source, the kelp Egregia menziesii, in northern California, USA. We found that P. producta fed selectively on E. menziesii, removing tissues with a high surface area to volume ratio (SA:V), which resulted in a $66 \%$ decrease in overall SA:V. Because these high SA:V tissues are disproportionately more responsible for nitrate uptake, selective herbivory by $P$. producta decreased E. menziesii's biomass-specific uptake of nitrogen, the primary limiting nutrient in this ecosystem, by $65 \%$ per gram of remaining algal tissue. In field surveys, where $P$. producta abundances were high, E. menziesii thalli more frequently exhibited signs of intense grazing and thus had lower SA:V ratios, suggesting that grazing is sufficiently intense in the field to generate differences in algal morphology and nitrate uptake. P. producta therefore influences $E$. menziesii biomass and productivity from the top down, by removing substantial amounts of biomass, and from the bottom up, by reducing the kelp's subsequent ability to acquire nutrients. Because of selective grazing on specialized tissues, the effects of mesoherbivores, like $P$. producta, on the structure and dynamics of marine communities may often be greater than predicted simply by the biomass they consume.
\end{abstract}

KEY WORDS: Herbivory $\cdot$ Nitrate uptake $\cdot$ Bottom-up processes $\cdot$ Top-down processes $\cdot$ Intertidal macroalgae $\cdot$ Nitrogen $\cdot$ Mesograzers

\section{INTRODUCTION}

Both consumer pressure and nutrient availability are important drivers of benthic marine community structure and dynamics (Menge 2000, Nielsen 2001). These top-down and bottom-up processes can also interact to influence organisms' distributions and abundances. For example, subsidies of nutrients, phytoplankton, and larvae associated with nearshore oceanographic conditions influence the magnitudes of species interactions in intertidal systems (Menge et al. 2003, 2004). Similarly, local-scale factorial manipulations of consumer abundance and nutrient availability in rocky intertidal communities suggest that the strength of topdown processes depends on the productivity of a site (Worm et al. 2002).

Because consumers influence nutrient availability (Porter 1976, Sterner 1986), top-down processes can also affect bottom-up processes. For example, marine invertebrates excrete inorganic nitrogen, primarily as ammonium, thereby enhancing the diversity and abundance of seaweeds in intertidal and nearshore communities (Williamson \& Rees 1994, Bracken 2004, Bracken \& Nielsen 2004). In some cases, there is a direct coupling between nitrogen excretion by an herbivore and nitrogen uptake by the algae it consumes, 
such that grazers simultaneously influence communities from both the top-down and from the bottom-up (Asmus \& Asmus 1991, Plagányi \& Branch 2000).

While consumers can clearly have positive effects on nutrient availability in marine ecosystems via nitrogen excretion, the negative impacts of consumers on bottom-up processes are less well understood. One way in which herbivores may negatively influence bottom-up processes is by selectively consuming the tissues or structures that are responsible for mediating these processes. For example, when mesograzers such as small crustaceans consume large macroalgae, they often target apical regions and small blades which are less morphologically or chemically defended (e.g. Pavia et al. 1999, Taylor et al. 2002). These structures are often characterized by high growth rates and surface area to volume ratios relative to other regions of the thallus, and they are therefore disproportionately responsible for seaweeds' nutrient uptake and photosynthesis (Wallentinus 1984, Hein et al. 1995, Stewart \& Carpenter 2003). Thus, even though mesograzers may remove relatively little biomass, their impact is often concentrated on tissues that are disproportionately important for nutrient uptake. As a result, their total effect on seaweed growth and fitness may be greater than currently appreciated.

We studied the interaction between kelp crabs Pugettia producta Randall and the kelp Egregia menziesii (Turner) Areschoug to evaluate the impacts of selective herbivory on macroalgal nitrogen uptake. We specifically quantified the effects of herbivory on nitrate uptake, because nitrate is the primary form of inorganic nitrogen available to low-intertidal macroalgae on waveswept northeastern Pacific shores (Fujita et al. 1989, Pfister \& Van Alstyne 2003), especially during the summer upwelling season when maximum E. menziesii growth occurs (Blanchette et al. 2002). Juvenile P. producta are often abundant on northern California rocky shores (Hines 1982), where they preferentially consume and live on E. menziesii thalli (Morris et al. 1980). In this study, we used field observations, outdoor mesocosm experiments, and laboratory measurements of nitrate uptake to quantify the effects of $P$. producta on $E$. menziesii biomass, morphology, and nitrogen uptake ability. Together, these measurements allowed us to characterize the top-down modification (selective grazing by P. producta) of a bottom-up process (nitrate uptake by E. menziezii) in a rocky intertidal community.

\section{MATERIALS AND METHODS}

Site characteristics and field surveys. Field surveys and collections were conducted on wave-exposed rocky intertidal reefs in the Bodega Marine Reserve, which is located on the northern California coast, USA $\left(38^{\circ} 19.0^{\prime} \mathrm{N}, 123^{\circ} 4.1^{\prime} \mathrm{W}\right)$. Surveys of Pugettia producta abundance and Egregia menziesii morphology were conducted along $10 \mathrm{~m}$ transects at 2 sites in the reserve: the West Channels (WC) and Horseshoe Cove (HC). We conducted these measurements in low-intertidal surge channels, where we counted every E. menziesii individual in the channel along each transect and measured the length of the longest frond growing out of each holdfast. We also quantified the number of $E$. menziesii individuals at each site that exhibited considerable grazing damage (Fig. 1). E. menziesii abundances were then normalized by channel area, which was determined by measuring the width of each channel at $1 \mathrm{~m}$ intervals and determining the area of the resulting polygon. We determined the number of $P$. producta per E. menziesii thallus at each of the 2 sites in the reserve by carefully lifting each frond and removing all attached crabs. Despite careful searching on other algae and on the substratum, kelp crabs were only found on E. menziesii thalli.

Algal morphology. We assessed whether differences in crab densities between sites were associated with differences in seaweed morphology that might affect the ability of seaweeds to take up nitrogen. We quantified variation in Egregia menziesii morphology by measuring the surface area to volume ratio $(\mathrm{SA}: \mathrm{V}$, in $\mathrm{cm}^{2} \mathrm{ml}^{-1}$ ) of randomly collected individuals ( $\mathrm{n}=12$ site $^{-1}$ ). The volume of each algal thallus (ml) was determined by displacement of water in a graduated cylinder, and the surface area was determined using a dye-coating technique (Stewart \& Carpenter 2003). Individual thalli were dipped for $15 \mathrm{~s}$ in a receptacle containing $1.6 \mathrm{~g}$ methylene blue and $20 \mathrm{ml}$ of Triton $10 \times$ detergent in $2000 \mathrm{ml}$ of de-ionized water. Algae were then spun briefly in a salad spinner (until no excess dye dripped off) and placed in a glass chamber containing $1500 \mathrm{ml}$ of de-ionized water. Algae were left in the chambers until all dye had diffused into the water ( 15 min). The concentration of dye was then read at $620 \mathrm{~nm}$ on a spectrophotometer. A calibration of dye concentrations based on known surface areas of blades of the red alga Mazzaella flaccida was used to calculate the surface area $\left(\mathrm{cm}^{2}\right)$ of each E. menziesii thallus (Stewart \& Carpenter 2003).

Effects of Pugettia producta on algal biomass and morphology. Ungrazed Egregia menziesii thalli $(\mathrm{n}=$ $30 ; 168.8 \pm 1.4 \mathrm{~g}$ wet tissue mass) and juvenile P. producta $(31.0 \pm 1.1 \mathrm{~mm}$ carapace width) were collected from the West Channels. E. menziesii were randomly assigned to treatments (+crab and -crab) and placed in 5.71 mesocosms. Mesocosms had plastic mesh sides to allow water flow and clear plastic tops to maximize light penetration. Mid-day photosynthetically active radiation within the mesocosms was $1138.2 \pm 61.7 \mu \mathrm{mol}$ 


\section{A. Ungrazed thallus}

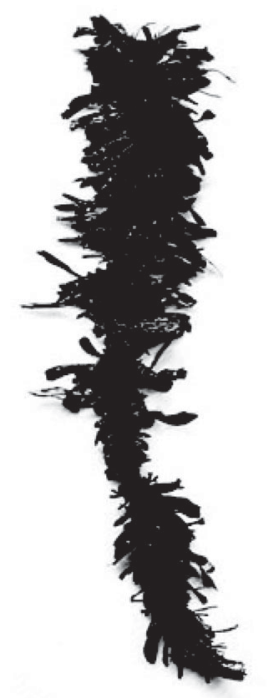

B. Grazed thallus

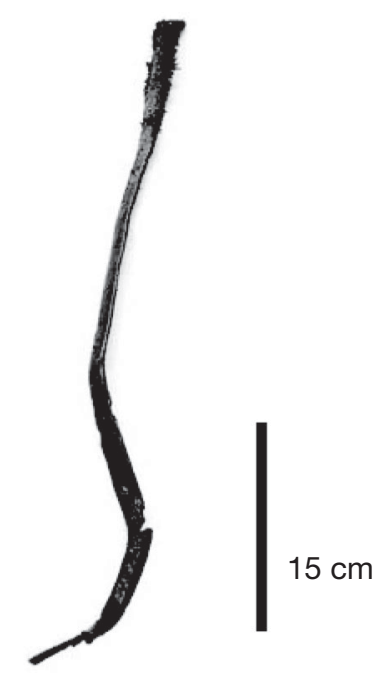

Fig. 1. Egregia menziesii. Variation in thallus morphology associated with kelp crab Pugettia producta grazing. Photos are of (A) an ungrazed thallus and (B) a heavily grazed thallus, both of which were collected from the West Channels, Bodega Marine Reserve. The ungrazed thallus is characterized by numerous bladelets on a central main stipe (rachis), whereas the bladelets have been selectively removed from the grazed thallus, and only the rachis remains

$\mathrm{m}^{-2} \mathrm{~s}^{-1}$. Crabs ( $\mathrm{n}=1$ or 2 to ensure constant consumer mass across treatments) were placed in +crab mesocosms, and mesocosms were randomly placed in 5 outdoor running seawater tanks $\left(10.5 \pm 0.1^{\circ} \mathrm{C}\right)$, with equal numbers of + crab and - crab treatments in each tank. We weighed each alga (wet tissue mass) every $4 \mathrm{~d}$ for $24 \mathrm{~d}$. The influence of $P$. producta grazing on E. menziesii morphology was determined by quantifying the $\mathrm{SA}: \mathrm{V}$ of seaweeds from the mesocosm experiment on Day 24 .

Effects of grazing on nitrate uptake by Egregia menziesii. Maintaining kelps for $24 \mathrm{~d}$ in the reducedflow conditions in our mesocosms dramatically altered their nitrate-uptake capabilities (M. Bracken \& J. Stachowicz unpubl. data). Therefore, in order to evaluate the influences of Pugettia producta grazing on nitrate uptake, we collected fresh E. menziesii thalli ( $\mathrm{n}=30$ ) from the field. We removed the bladelets from half of the E. menziesii individuals with scissors, to produce thalli that mimicked those naturally grazed by $P$. producta (Fig. 1). We then compared the nitrate uptake abilities of the ungrazed and artificially grazed individuals. To quantitatively assess the morphological effects of grazing by kelp crabs versus manual removal of bladelets, we compared the SA:V ratios of 15 ungrazed and 15 simulated-grazed individuals with the SA:V

ratios of the grazed and ungrazed thalli from the $P$. producta grazing experiment (see above). Manual removal altered $\mathrm{SA}: \mathrm{V}$ in a quantitatively similar manner to actual grazing (see 'Results'), so manual removal adequately mimicked the morphological effect of $P$. producta grazing.

Because wounding seaweeds, even without removing tissues, can influence their physiological rates (Knoop \& Bate 1988), we conducted a second set of experimental trials to evaluate the effects of tissue damage on nitrate uptake. We collected additional individuals of Egregia menziesii ( $\mathrm{n}=30$ ) from the Bodega Marine Reserve. We nicked the bladelets of half of the individuals with scissors, which caused roughly the same degree of tissue damage but had no effect on SA:V (see 'Results'). We then compared the nitrate-uptake abilities of the undamaged and damaged individuals. Because efflux of nitrate from damaged bladelet tissues (see 'Results') confounded our ability to measure initial nitrate concentrations and calculate Michaelis-Menten nitrate uptake parameters, we conducted a second set of nitrate uptake trials on the same individuals $40 \mathrm{~h}$ after damaging them.

All nitrogen uptake trials were conducted in a temperature-controlled room, and experimental chambers were partially submerged in a running seawater bath, which maintained temperatures at $15.7 \pm 0.3^{\circ} \mathrm{C}$ during the experiment. While the halogen lamps used to illuminate the chambers (see below) caused the chambers to be slightly warmer than average ambient seawater temperatures, they were still within the range of typical seawater temperatures in northern California nearshore waters (recorded at the Bodega Ocean Observing Node; www.bml.ucdavis.edu/boon/). Aquarium pumps (Aquarium Systems) were used to recirculate the water within each chamber, and they created turbulent flows of $9.7 \pm 0.1 \mathrm{~cm} \mathrm{~s}^{-1}$, which was sufficient to ensure maximum rates of nitrate uptake (Wheeler 1982). Water velocities were measured in the middle of each chamber using a Vectrino Velocimeter (Nortek AS). These velocities are sufficient $\left(>3 \mathrm{~cm} \mathrm{~s}^{-1}\right)$ to generate turbulence over fronds of Egregia menziesii (Hurd \& Stevens 1997). The turbulent nature of the flow environment was verified by calculating the turbulence intensity $(I)$ :

$$
I=\frac{\sqrt{\overline{\sigma^{2}}}}{u}
$$

where $\overline{\sigma^{2}}$ is the mean square of the standard deviations of the flow vectors and $u$ is the velocity. In this case, $I=$ 1.4, suggesting that the flow was, indeed, turbulent. Four Luma-Pro $500 \mathrm{~W}$ quartz halogen lamps (Grainger International) provided $498.5 \pm 35.8 \mu \mathrm{mol} \mathrm{m} \mathrm{m}^{-2} \mathrm{~s}^{-1}$ of photosynthetically active radiation. 
We added nitrate as $\mathrm{NaNO}_{3}$ to 15 cylindrical glass chambers containing 21 of nitrogen-free artificial seawater, supplying Egregia menziesii thalli with initial nitrate concentrations of approximately 2, 6, 12, 20, and $30 \mu \mathrm{mol} \mathrm{l}^{-1}$. These nitrate concentrations spanned the range of concentrations typically available in the nearshore waters of the Bodega Marine Reserve. For each treatment (ungrazed and artificially grazed), we measured nitrate depletion rates of individual E. menziesii thalli in 3 replicate chambers at each initial nitrogen concentration. We collected $5 \mathrm{ml}$ water samples at 15 min intervals for 75 min and analyzed the samples for nitrate concentrations using a nutrient autosampler (Lachat Instruments). We then used the rate of nitrate depletion and the dry tissue mass of each thallus (dried at $60^{\circ} \mathrm{C}$ to constant mass) to evaluate the biomassspecific nitrate uptake rate of each thallus $\left(\mu \mathrm{mol} \mathrm{h} \mathrm{h}^{-1}\right.$ $\mathrm{g}^{-1}$ ) as a function of initial nitrate concentration. We also evaluated changes in nitrate concentration in control chambers, which were identical to the experimental chambers, but lacked E. menziesii. We never detected changes (either increases or decreases) in nitrate concentrations in the control chambers, regardless of initial nitrate concentration $(t<1.36$, $\mathrm{p}>0.19)$, so the uptake values we present are based strictly on depletion of nitrate from the water column. We related nitrate concentration to nitrate uptake using the Michaelis-Menten equation (Lobban \& Harrison 1994). We compared Michaelis-Menten and linear relationships for both grazed and ungrazed thalli, and found that the Michaelis-Menten equation provided a better fit to the data based on the variance explained $\left(F_{1,58}=\right.$ $4.22, \mathrm{p}=0.044)$, indicating that nitrate uptake saturated with increasing initial concentration.

Statistical analyses. Most analyses were conducted using general linear models (GLMs) and $t$-tests in SAS v. 9.1 (SAS Institute). GLMs included analyses of variance (ANOVAs) and repeated-measures ANOVAs. Some of the field survey data (Pugettia producta abundances and Egregia menziesii SA:V) were either not normally distributed or variances were not homogeneous, so we used Wilcoxon nonparametric, 2-sample tests to compare the sampled populations.

\section{RESULTS}

\section{Effects of Pugettia producta on Egregia menziesii biomass and morphology}

Egregia menziesii was abundant at both sites (WC: $3.9 \pm 1.2$ thalli $\mathrm{m}^{-2}$; HC: $5.2 \pm 2.3$ thalli $\mathrm{m}^{-2}$ ), and sites did not differ with respect to $E$. menziesii density $\left(F_{1,18}\right.$ $=0.27, \mathrm{p}>0.60)$ or average length $\left(F_{1,28}=0.49, \mathrm{p}=\right.$ 0.49), suggesting that patterns of Pugettia producta distribution were not associated with differences in the amount of (pre-grazing) habitat available to them. $P$. producta were more abundant at WC than at $\mathrm{HC}$ (Wilcoxon 2-sample test: $Z=2.01, \mathrm{p}=0.045$ ) (Fig. 2A). We found a crab on 1 out of every 7 thalli at WC, versus 1 out of every 55 thalli at HC. These differences in crab abundances were correlated with differences in E. menziesii morphology, consistent with more intense grazing at WC. Algae from WC had lower mean SA:V ratios than those at $\mathrm{HC}$ (Wilcoxon 2-sample test: $Z=$ 2.03, p = 0.043) (Fig. 2B). At WC, $33 \%$ of thalli exhibited appreciable grazing damage (rachises without bladelets; Fig. 1B), whereas at HC, only $11 \%$ of thalli were heavily grazed. When these heavily grazed individuals were excluded from the analysis, E. menziesii from the 2 sites were morphologically indistinguishable $\left(F_{1,17}=0.58, \mathrm{p}=0.455\right)$, suggesting that grazing, and not some other site-specific factor, was responsible for the differences described above.

When we enclosed Pugettia producta with Egregia menziesii thalli in mesocosms, the crabs consumed algal biomass, altering the kelps' morphology. E. menziesii masses in +crab and -crab treatments were indistinguishable on Day $0\left(F_{1,28}=0.27, \mathrm{p}=0.605\right)$, but grazing by $P$. producta resulted in appreciable declines in biomass by Day $4\left(F_{1,28}=20.72, \mathrm{p}<0.001\right)$, a trend which continued throughout the duration of the exper-
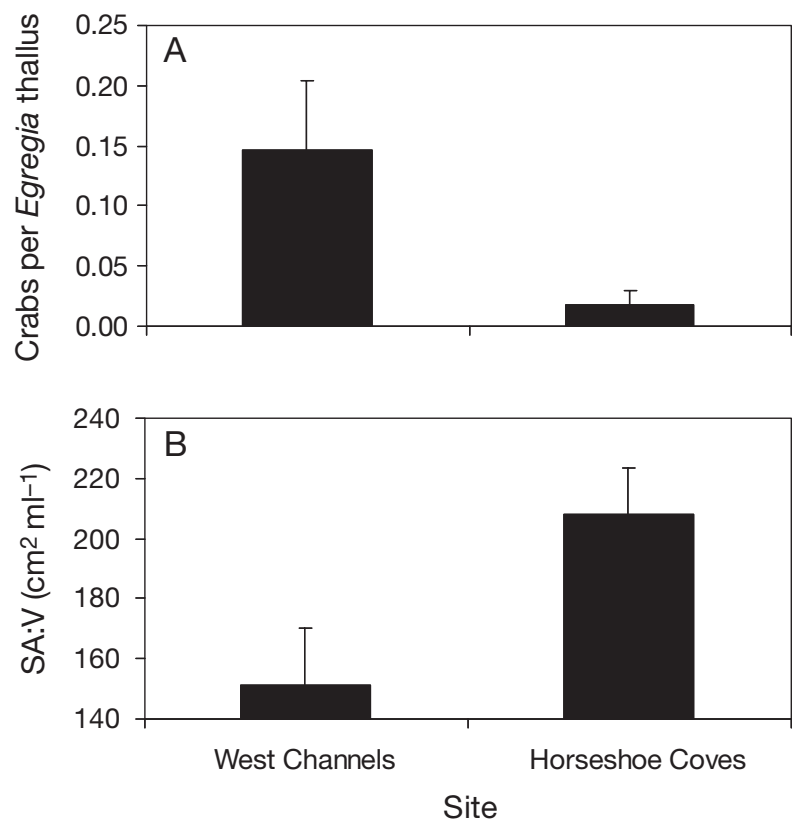

Fig. 2. Pugettia producta and Egregia menziesii. Kelp crab abundances and E. menziesii morphology at 2 sites in the Bodega Marine Reserve. (A) Kelp crabs are more abundant at the West Channels, where (B) surface area to volume ratios $(\mathrm{SA}: \mathrm{V})$ of E. menziesii thalli are lower. Values are means + standard errors 


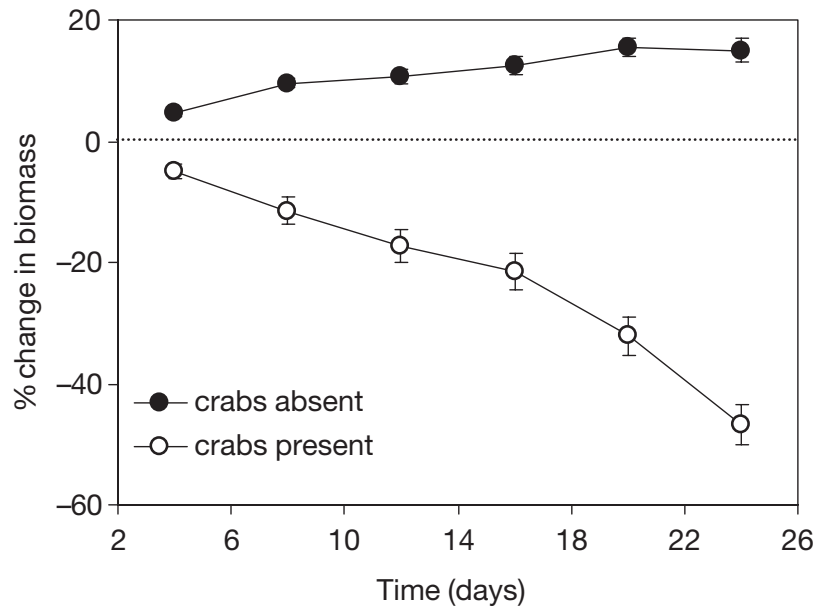

Fig. 3. Egregia menziesii. Influences of kelp crab Pugettia producta grazing on E. menziesii biomass in experimental mesocosms. Where crabs were absent, E. menziesii biomass increased by $15 \%$, whereas, where crabs were present, biomass declined by $47 \%$. Values are means \pm standard errors

iment (repeated-measures ANOVA: time $\times$ crabs interaction; $\left.F_{6,168}=144.5, \mathrm{p}<0.001\right)$. In the absence of crabs, seaweed biomass increased, whereas, where crabs were present, seaweeds lost biomass, resulting in a $62 \%$ difference in biomass between the treatments after $24 \mathrm{~d}$ (Fig. 3). Further, we found that kelp crabs selectively removed the bladelets from the rachis, resulting in a dramatic $(66 \%)$ decline in $\mathrm{SA}: \mathrm{V}\left(F_{1,28}=\right.$ 37.39, p < 0.001) (Fig. 4).

\section{Effects of grazing on nitrate uptake by Egregia menziesii}

When grazing was simulated by manually removing bladelets from the rachis of each 'grazed' individual, changes in SA:V were similar to those associated with Pugettia producta grazing in the outdoor mesocosms. Morphologically, thalli subjected to manual bladelet removals were indistinguishable from those grazed by P. producta $\left(F_{1,28} \leq 0.15, \mathrm{p} \geq 0.698\right)$ and exhibited a similar $(68 \%)$ reduction in SA:V relative to unclipped controls $\left(F_{1,28}=61.28, \mathrm{p}<0.001\right.$; Fig. 4). Removal of the bladelets decreased the ability of Egregia menziesii to utilize nitrate (Fig. 5). When bladelets were removed, the Michaelis-Menten half-saturation constant $\left(K_{\mathrm{s}}\right)$ increased from $12.4 \pm 0.3$ to $20.0 \pm 0.5 \mu \mathrm{mol} \mathrm{l} \mathrm{l}^{-1}(t=$ 13.27, $\mathrm{df}=28, \mathrm{p}<0.001)$, and the maximal uptake velocity $\left(V_{\max }\right)$ decreased from $1.4 \pm 0.3$ to $0.6 \pm$ $0.1 \mu \mathrm{mol} \mathrm{h}{ }^{-1} \mathrm{~g}^{-1}(t=2.34, \mathrm{df}=28, \mathrm{p}=0.027)$. Bladelet removal thus resulted in a 4 -fold reduction in the nitrate uptake coefficient $\left(\alpha=V_{\mathrm{max}} / K_{\mathrm{si}}\right.$ Harrison et al. 1989) from $0.11 \pm 0.02$ to $0.03 \pm 0.01(t=3.29$, $\mathrm{df}=28$,

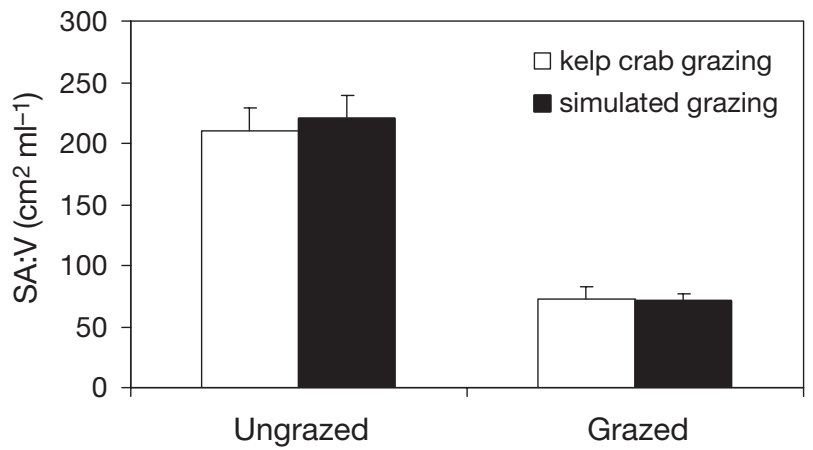

Fig. 4. Egregia menziesii. Grazing by kelp crabs Pugettia producta influences macroalgal morphology. Kelp crabs selectively remove bladelets from the rachis, reducing the surface area to volume ratio (SA:V) of the algal thallus (open bars). Morphological changes associated with simulated grazing (manual removal of bladelets) are indistinguishable from those associated with $P$. producta grazing (filled bars). Values are means + standard errors

$\mathrm{p}=0.003)$. Furthermore, uptake rates of individuals whose bladelets were removed actually declined over time $\left(F_{4,52}=40.08, \mathrm{p}<0.001\right)$, suggesting that they do not have the potential to recover from this damage, at least on a short-term basis. Based on these measurements and local seawater nitrate concentrations during

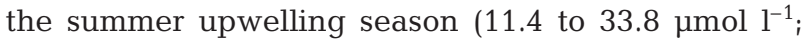
M. Bracken unpubl. data), grazing has the potential to reduce the amount of nitrate available to $E$. menziesii by up to $65 \%$.

Damaging the bladelets without removing any algal tissue did not alter the SA:V of the algal thalli relative to undamaged controls $(t=1.697$, $\mathrm{df}=28, \mathrm{p}=0.101)$. In

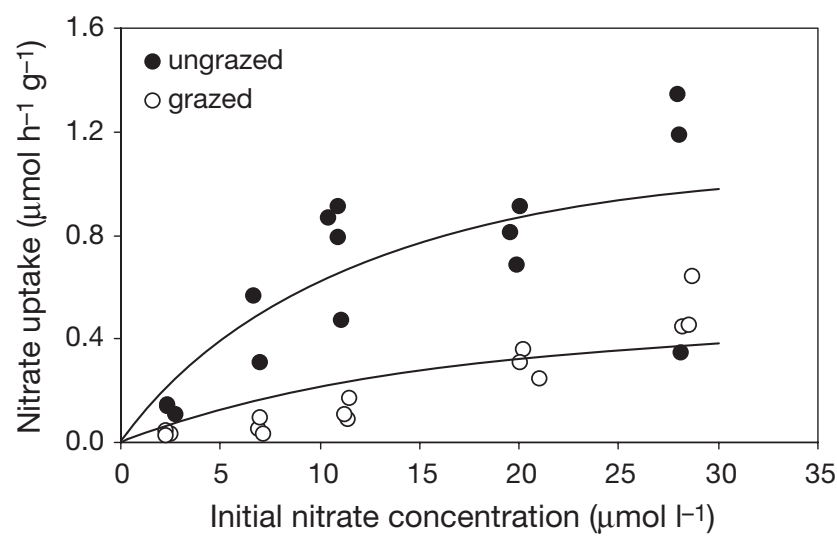

Fig. 5. Egregia menziesii. Selective grazing by kelp crabs Pugettia producta reduces nitrate uptake by E. menziesii. Grazing was simulated by manually removing bladelets, which mimicked morphological modification associated with kelp crab grazing. Curves were fit using the MichaelisMenten equation $\left(r^{2}=0.58\right.$ for ungrazed thalli and $r^{2}=0.78$ for grazed thalli) 
fact, the SA:V of damaged individuals was slightly higher than that of the controls. However, in contrast to controls, nicking the bladelets resulted in an immediate increase in water-column nitrate levels. This initial nitrate efflux, which averaged $2.03 \pm 0.86 \mu \mathrm{mol} \mathrm{h}{ }^{-1} \mathrm{~g}^{-1}$ $(t=2.36, \mathrm{df}=14, \mathrm{p}=0.033)$, lasted approximately $30 \mathrm{~min}$, after which time the seaweeds began taking up nitrate at an average rate of $1.67 \pm 0.21 \mu \mathrm{mol} \mathrm{h}^{-1} \mathrm{~g}^{-1}$, which was actually higher than that of the undamaged controls $\left(0.50 \pm 0.06 \mu \mathrm{mol} \mathrm{h}-1 \mathrm{~g}^{-1} ; t=2.68, \mathrm{df}=28, \mathrm{p}=\right.$ $0.012)$. Nitrate uptake by those same damaged individuals was measured $40 \mathrm{~h}$ after wounding to assess their subsequent recovery. Michaelis-Menten uptake parameters of seaweeds with damaged, but unremoved, bladelets $\left(K_{\mathrm{s}}=13.2 \pm 0.3\right.$ and $\left.V_{\max }=2.3 \pm 0.4\right)$ were comparable to (and slightly higher than) those of undamaged individuals $(t \leq 1.89, \mathrm{df}=28, \mathrm{p} \geq 0.070)$.

\section{DISCUSSION}

Our results suggest that consumption of Egregia menziesii by Pugettia producta influences not only E. menziesii biomass (Fig. 3), but also the subsequent physiological performance of the seaweed. Specifically, kelp crabs selectively removed E. menziesii bladelets, specialized regions of the algal thallus which are disproportionately responsible for nitrate uptake due to their high SA:V (Fig. 4). This selective herbivory reduced the biomass-specific nitrate uptake ability of E. menziesii thalli by $>60 \%$ (Fig. 5). Because assimilation of nitrate is an energetically expensive process (Lobban \& Harrison 1994), the reduced ability of grazed individuals to take up nitrate was likely associated with both direct effects of lower SA:V on the seaweeds' abilities to transport nitrate and with indirect effects on nitrate assimilation due to lower rates of photosynthesis. Because nitrogen is the primary growth-limiting nutrient in temperate coastal ecosystems (Ryther \& Dunstan 1971), this reduction in the ability of $E$. menziesii to effectively obtain nitrate is likely to have profound impacts on the seaweed's recovery from grazing and its subsequent growth.

Our measurements of initial transient nitrate efflux by individuals that were damaged without changing their SA:V supports earlier findings that wounding can influence the physiological rates of seaweeds (Knoop \& Bate 1988). The increases in water-column nitrate concentrations associated with nicking the bladelets were probably caused by the physical disruption of internal pools of nitrate (Chapman \& Craigie 1977). This stored nitrate is likely to be localized in the bladelets, where the majority of nitrate uptake occurs. The rapid recovery of these individuals suggests that the effects of wounding, per se, on nitrate uptake are short-lived. In contrast, the reduction in SA:V associated with removal of bladelets by $P$. producta is likely to have longer-term negative impacts on the ability of E. menziesii to take up nitrate.

Our mesocosm-based experimental approach likely overestimated the impacts of Pugettia producta in the field. Although we occasionally counted several individual $P$. producta on a single thallus, we found a kelp crab on an average of only 1 out of every 7 thalli at the West Channels, where abundances were highest. We placed 1 or 2 P. producta individuals (depending on biomass) and 1 macroalgal thallus in each +crab mesocosm, so our results reflect maximum, rather than average, potential impacts of $P$. producta on E. menziesii morphology and nitrate uptake. Furthermore, herbivory rates are likely to be somewhat lower under field conditions due to the difficulty of feeding in highflow surge channels relative to low-flow mesocosms (Nielsen 2001). Despite these limitations, the prevalence of heavily grazed thalli in the field (Fig. 1), especially in the West Channels, and the observed relationship between higher $P$. producta abundances and reduced E. menziesii SA:V (Fig. 2) suggest that the interaction we describe here does occur on waveswept rocky shores.

While this is the first demonstration, to our knowledge, of an herbivore's effect on nutrient uptake by a seaweed, similar impacts of herbivory on nutrient uptake and photosynthesis have been identified in terrestrial and nearshore marine ecosystems. For example, sublethal defoliation of terrestrial plants can alter transpiration rates and root biomass, which can decrease nitrogen and phosphorus uptake from the soil (Chapin \& Slack 1979, Brown 1994). Similarly, selective grazing by limpets on marine angiosperms (Zostera marina in soft-sediment habitats and Phyllospadix scouleri in rocky intertidal systems) reduces photosynthetic rates and alters growth and productivity (Barbour \& Radosevich 1979, Zimmerman et al. 1996). In both seagrass species, limpets selectively remove the epidermis, which comprises $<10 \%$ of the leaf biomass in $Z$. marina, but $>90 \%$ of the chlorophyll. Furthermore, because grazers often target high SA:V tissues because of their low toughness or high nutritive value (Pavia et al. 1999, Taylor et al. 2002), we suspect that sublethal effects of herbivory on bottom-up processes may be an important aspect of community dynamics in many different systems. While small grazers may also have positive effects via nutrient recycling (Taylor \& Rees 1998), such benefits may be diminished if direct grazing removes structures that facilitate nutrient uptake.

Our results highlight how mesoherbivores can influence the structure and dynamics of marine communities in ways that are greater than predicted by the grazers' abundances or biomass consumption. Remo- 
val of large amounts of macroalgal or epiphyte biomass by mesoherbivores does occur (e.g. Brawley \& Fei 1987, Ruesink 2000, Graham 2002), but may be relatively uncommon, because densities of grazers are often kept to low levels by their predators (Nelson 1979, Duffy \& Hay 2000). However, by grazing selectively on disproportionately important tissues, mesoherbivores can have large per capita negative effects on kelps and other large, dominant macrophytes. In our study, Pugettia producta reduced the biomassspecific nutrient-uptake capability of Egregia menziesii via selective removal of bladelets, but a wide range of mechanisms may underlie strong per capita mesograzer effects. For example, the subtidal snail Lacuna vincta removes very little biomass from kelp stipes, but causes greatly increased rates of stipe breakage in low to moderate flows (Duggins et al. 2001). Furthermore, mesograzers are known to preferentially feed on the reproductive structures of intertidal macroalgae (Gaines 1985, Buschmann \& Santelices 1987) and may thereby have impacts on algal fitness that are greater than predicted by the amount of biomass they consume. In E. menziesii, sporophylls are interspersed among the vegetative bladelets, are morphologically similar to them (Abbott \& Hollenberg 1976), and were also readily consumed by the crabs (M. Bracken pers. obs.). P. producta may therefore negatively affect $E$. menziesii both by modifying the seaweed's ability to take up nitrogen and also by removing reproductive structures.

In summary, we have demonstrated that a mesoherbivore, the kelp crab Pugettia producta, selectively feeds on Egregia menziesii by removing the bladelets, which are disproportionately responsible for the majority of the seaweed's nitrate uptake. Based on these results, we suggest that the influences of grazers, especially mesoherbivores, on nutrient uptake may represent an important, often overlooked factor influencing the structure and functioning of intertidal communities and ecosystems.

Acknowledgements. We thank S. Williams for laboratory space, equipment, and advice; B. Bracken, J. Byrnes, A. Carranza, A. Chaudoin, M. Faubel, S. Lund, P. Reynolds, and C. Sorte for research assistance; and C. Sorte, C. Thornber, and 2 anonymous reviewers for helpful comments on the manuscript. This research was supported by the National Science Foundation (OCE-0351778 to J.J.S.). This is Contribution Number 2350 of the Bodega Marine Laboratory, University of California, Davis.

\section{LITERATURE CITED}

Abbott IA, Hollenberg GJ (1976) Marine algae of California. Stanford University Press, Stanford, CA

Asmus RM, Asmus H (1991) Mussel beds: limiting or promoting phytoplankton? J Exp Mar Biol Ecol 148:215-232
Barbour MG, Radosevich SR (1979) ${ }^{14} \mathrm{C}$ uptake by the marine angiosperm Phyllospadix scouleri. Am J Bot 66:301-306

Blanchette CA, Miner BG, Gaines SD (2002) Geographic variability in form, size and survival of Egregia menziesii around Point Conception, California. Mar Ecol Prog Ser 239:69-82

Bracken MES (2004) Invertebrate-mediated nutrient loading increases growth of an intertidal macroalga. J Phycol 40: 1032-1041

Bracken MES, Nielsen KJ (2004) Diversity of intertidal macroalgae increases with nutrient loading by invertebrates. Ecology 85:2828-2836

Brawley SH, Fei XG (1987) Studies of mesoherbivory in aquaria and in an unbarricaded mariculture farm on the Chinese coast. J Phycol 23:614-623

Brown DG (1994) Beetle folivory increases resource availability and alters plant invasion in monocultures of goldenrod. Ecology 75:1673-1683

Buschmann A, Santelices B (1987) Micrograzers and spore release in Iridaea laminarioides Bory (Rhodophyta: Gigartinales). J Exp Mar Biol Ecol 108:171-179

Chapin FS III, Slack M (1979) Effect of defoliation upon root growth, phosphate absorption and respiration in nutrientlimited tundra graminoids. Oecologia 42:67-79

Chapman ARO, Craigie JS (1977) Seasonal growth in Laminaria longicruris: relations with dissolved inorganic nutrients and internal reserves of nitrogen. Mar Biol 40: $197-205$

Duffy JE, Hay ME (2000) Strong impacts of grazing amphipods on the organization of a benthic community. Ecol Monogr 70:237-263

Duggins D, Eckman JE, Siddon CE, Klinger T (2001) Interactive roles of mesograzers and current flow in survival of kelps. Mar Ecol Prog Ser 223:143-155

Fujita RM, Wheeler PA, Edwards RL (1989) Assessment of macroalgal nitrogen limitation in a seasonal upwelling region. Mar Ecol Prog Ser 53:293-303

Gaines SD (1985) Herbivory and between-habitat diversity: the differential effectiveness of defenses in a marine plant. Ecology 66:473-485

Graham MH (2002) Prolonged reproductive consequences of short-term biomass loss in seaweeds. Mar Biol 140: 901-911

Harrison PJ, Parslow JS, Conway HL (1989) Determination of nutrient uptake kinetic parameters: a comparison of methods. Mar Ecol Prog Ser 52:301-312

Hein M, Pedersen MF, Sand-Jensen K (1995) Size-dependent nitrogen uptake in micro- and macroalgae. Mar Ecol Prog Ser 118:247-253

Hines AH (1982) Coexistence in a kelp forest: size, population dynamics, and resource partitioning in a guild of spider crabs (Brachyura, Majidae). Ecol Monogr 52:179-198

Hurd CL, Stevens CL (1997) Flow visualization around singleand multiple-bladed seaweeds with various morphologies. J Phycol 33:360-367

Knoop WT, Bate GC (1988) The effect of wounding on the photosynthetic rates of three subtidal rhodophytes. Bot Mar 31:149-153

Lobban CS, Harrison PJ (1994) Seaweed ecology and physiology. Cambridge University Press, New York

Menge BA (2000) Top-down and bottom-up community regulation in marine rocky intertidal habitats. J Exp Mar Biol Ecol 250:257-289

Menge BA, Lubchenco J, Bracken MES, Chan F and 9 others (2003) Coastal oceanography sets the pace of rocky intertidal community dynamics. Proc Natl Acad Sci USA 100: 12229-12234 
Menge BA, Blanchette C, Raimondi P, Freidenburg T and 6 others (2004) Species interaction strength: testing model predictions along an upwelling gradient. Ecol Monogr 74: 663-684

Morris RH, Abbott DP, Haderlie EC (1980) Intertidal invertebrates of California. Stanford University Press, Stanford, CA

Nelson WG (1979) An analysis of structural pattern in an eelgrass (Zostera marina L.) amphipod community. J Exp Mar Biol Ecol 39:231-264

Nielsen KJ (2001) Bottom-up and top-down forces in tide pools: test of a food chain model in an intertidal community. Ecol Monogr 71:187-217

Pavia H, Carr H, Åberg P (1999) Habitat and feeding preferences of crustacean mesoherbivores inhabiting the brown seaweed Ascophyllum nodosum (L.) Le Jol. and its epiphytic macroalgae. J Exp Mar Biol Ecol 236:15

Pfister CA, Van Alstyne KL (2003) An experimental assessment of the effects of nutrient enhancement on the intertidal kelp Hedophyllum sessile (Laminariales, Phaeophyceae). J Phycol 39:285-290

Plagányi ÉE, Branch GM (2000) Does the limpet Patella cochlear fertilize its own algal garden? Mar Ecol Prog Ser 194:113-122

Porter KG (1976) Enhancement of algal growth and productivity by grazing zooplankton. Science 192:1332-1334

Ruesink JL (2000) Intertidal mesograzers in field microcosms: linking laboratory feeding rates to community dynamics. J Exp Mar Biol Ecol 248:163-176

Editorial responsibility: Howard Browman (Associate Editorin-Chief), Storebø, Norway
Ryther JH, Dunstan WM (1971) Nitrogen, phosphorus, and eutrophication in the coastal marine environment. Science 171:1008-1013

Sterner RW (1986) Herbivores' direct and indirect effects on algal populations. Science 231:605-607

Stewart HL, Carpenter RC (2003) The effects of morphology and water flow on photosynthesis of marine macroalgae. Ecology 84:2999-3012

Taylor RB, Rees TAV (1998) Excretory products of mobile epifauna as a nitrogen source for seaweeds. Limnol Oceanogr 43:600-606

Taylor R, Sotka E, Hay M (2002) Tissue-specific induction of herbivore resistance: seaweed response to amphipod grazing. Oecologia 132:68-76

Wallentinus I (1984) Comparisons of nutrient uptake rates for Baltic macroalgae with different thallus morphologies. Mar Biol 80:215-225

Wheeler WN (1982) Nitrogen nutrition of Macrocystis. In: Srivastava LM (ed) Synthetic and degradative processes in marine macrophytes. Walter de Gruyter \& Co., Berlin, p 121-137

Williamson JE, Rees TAV (1994) Nutritional interaction in an alga-barnacle association. Oecologia 99:16-20

Worm B, Lotze HK, Hillebrand H, Sommer U (2002) Consumer versus resource control of species diversity and ecosystem functioning. Nature 417:848-851

Zimmerman RC, Kohrs DG, Alberte RS (1996) Top-down impact through a bottom-up mechanism: the effect of limpet grazing on growth, productivity and carbon allocation of Zostera marina L. (eelgrass). Oecologia 107:560-567

Submitted: November 17, 2005; Accepted: June 13, 2006 Proofs received from author(s): January 9, 2007 